\title{
QUESTIONING DEMOCRACY IN THE NAME OF THE PEOPLE: THE SO-CALLED “NEW LATIN AMERICAN CONSTITUTIONALISM”
}

\author{
Carlos Flores Juberías \\ University of Valencia, Spain \\ carlos.flores@uv.es
}

\begin{abstract}
Throughout the last decade, an academic approach has become increasingly vocal, stating that, notwithstanding the many differences between the constitutional texts that have been adopted in several Latin American countries as a result of the successive victories of populist candidates like Hugo Chavez in Venezuela, Rafael Correa in Ecuador and Evo Morales in Bolivia, some shared concerns and some common features can be identified, revealing the existence of a "New Latin American Constitutionalism", the ultimate goal of which would be to provide for these countries a valid replacement of the old fashioned European liberal traditions by new political systems, more suited to the realities, the problems and the expectations of Latin American peoples. In this paper, I will try (1) to make a presentation of the political climate in which these constitution-making processes were carried out; (2) to provide an enumeration of the basic features that have given consistency to the idea that there is a new constitutionalist stream emerging in this part of the world; and (3) to debate about how new, and how detached from the well established European tradition this "new Latin American constitutionalism" is, and how efficient the solutions proposed have been in order to improve the political stability of Latin American states and enlarging the scope of rights and liberties enjoyed by their citizens.
\end{abstract}

Keywords: Latin America, Constitution, Democracy, Populism, Human Rights

\section{Introduction}

To argue that we are witnessing the beginning of a new era in the evolution of Constitutional Law is not something frequently heard. If there is a discipline in legal sciences that seems resistant to the temptations of modernization, and prefers above 
anything else to remain sheltered under the formulas endorsed by experience, that discipline is Constitutional Law, an area where innovation is difficult and experimentation is usually greeted with suspicion. Probably the reason for this lies in the intimate relationship between democracy as a goal and constitutionalism as a mean to achieve it, a relationship that has as a consequence that any innovation in the field of constitutionalism has to go through the test of whether it is sufficiently committed to the most deeply rooted democratic values or not, and if it will serve them with the same effectiveness of the already known formulas.

Perhaps for this reason, in explaining the evolution of Constitutional Law over the past two hundred years or so, it is usual to just point out the existence of four major periods:

- Liberal revolutionary constitutionalism, a by-product of the bourgeois revolutions of late eighteenth and early nineteenth century, the best products of which would be the American Constitution of 1787, the 1791 Polish Constitution, the French Constitution of that same year, or the Spanish 1812 Constitution.

- The conservative reaction, provoked by the convergence between the bourgeoisie and the old (or new) dynasties and aristocracies, which had its heyday during the 19th century and the early years of the 20th century.

- Democratic constitutionalism, which emerged after the defeat of the Central Empires in World War I, and was embodied in texts of as much significance as the Weimar Constitution of 1919, the Spanish 1931 Constitution or -in the Americasthe Mexican Constitution of 1917.

- And, finally, social constitutionalism, paradigmatic of developments following World War II, of which the French constitutions of 1946, the Italian of 1947 and the German of 1949 are the best and earlier examples and the Portuguese of 1976 and the Spanish of 1978 rather remarkable and later ones.

However, in the last years, an academic approach has become increasingly vocal, and is also becoming gradually accepted both among the academic community and at the political sphere in the Hispanic world, that states that, notwithstanding the many differences between the constitutional texts that have been recently adopted in several Latin American countries as a result of a series of successive constituent processes, some common features or identifying traits, which reveal the existence of some shared concerns, can very well be identified; and that these coincidences have paved the way for the 
emergence of a so-called "New Latin American Constitutionalism"(Viciano Pastor \& Martínez Dalmau, 2011), the ultimate goal of which would be to provide for these countries a global replacement of the old fashioned European constitutional models imported throughout the $19^{\text {th }}$ Century, and the introduction of new constitutional frameworks, more suited to the traditions, values, and realities of Latin American peoples. And, if possible, to question some of the paradigms that have defined the evolution of constitutionalism so far.

In this paper, I will try to provide a summary presentation of those features that have been giving consistency to the idea that there is a new constitutional tendency in this continent, in order to pave the way for a debate about how new, and how detached from the well established European tradition this "New Latin American Constitutionalism" is. Unfortunately, the debate about how efficient the solutions proposed have been in order to improve the political stability of Latin American countries and enlarge the scope of rights and liberties enjoyed by their citizens will exceed the possibilities of a short contribution like this, and will only be briefly introduced.

\section{The Origins of the New Latin American Constitutionalism}

Leaving aside such valuable attempts at consolidating democracy and advancing in the protection of human rights as those contained in the Guatemalan Constitution of 1985 (Martínez Sospedra, 1995) and the Brazilian Constitution of 1988 (Bravo Lira, 1989), it is widely accepted that the series of constituent processes that have given grounds to coining the term "New Latin American Constitutionalism" started with the one initiated in Colombia in 1990, which had as a result the Colombian Constitution of 1991 (Noguera Fernández \&Criado de Diego, 2011). Both the constitution-making process and the Constitution itself already featured the main characteristics of what is now defining this new constitutionalism: on the one hand a political proposal for the overcoming of an obsolete constitutional framework (which in Colombia dated back to 1886) and the reconstruction of the State, preceded by a broad social mobilization, and leading to a fully democratic and highly participative constituent Assembly; and on the other hand a strong constitutional text, largely innovative and with a huge transformational potential.

Again, leaving aside other valuable but rather limited attempts of political transformation as those verified in Peru in 1993 (Fernández Segado, 1994) and in Argentina in 1994 (Jiménez, 2004), the Colombian experience was renewed by the new Ecuadorian Constitution of 1998 (Trujillo Vásquez, Viciano Pastor \&Andrade Ubidia, 2005), though the lack of a final referendum on the constitutional draft -as it had already happened in 
Colombia- and the conflict between the constituent Assembly and the ordinary branches of power, weakened the legitimacy of the new Constitution, which ended up being repealed by a second constituent process only ten years later.

The Venezuelan constitution-making process of 1999 (Martínez Dalmau, 2006), on the other hand, not only featured all participatory elements of more democratic constituent processes -including a referendum to activate the process and another one to close it, approving its constitutional text- but its final outcome -the Constitution of 1999 (Viciano Pastor \& Salamanca, 2006), backbone of the Chavez regime- fully encompasses the elements which in the following sections I will try to enumerate as characteristics of this new constitutionalism.

For the time being, the last samples of this happen to be the new Ecuadorian constituent process of 2007-2008, promoted by President Rafael Correa (Ávila Santamaria, Grijalva Jiménez \&Martínez Dalmau, 2008), and almost simultaneously the constituent process experienced by Bolivia between 2006 and 2009, under the leadership of President Evo Morales (Gamboa, 2011), whose outcome, the Bolivian Constitution of 2009 (Chivi Vargas, 2010) is one of the most clear examples of deep institutional transformation experienced in Latin America in decades.

This relatively rapid succession of constituent assemblies and constitutional referenda which lies at the root of most of the texts to which we have just referred to, could easily be identified as the first defining characteristic of the New Latin American Constitutionalism, since its simple verification already marked a sudden depart from the most usual practices in the Latin American context, where constitutions were usually drafted and passed strictly within the confines of parliament (Viciano Pastor \& Martínez Dalmau, 2010).

In fact, since the adoption of the first, foundational constitutions of the States of the region, during the second and third decades of the 19th century, Latin America had lacked of constituent processes that might be qualified as truly popular, and even democratic. The many -occasionally, excessive - constitutional innovations in the continent had normally been the result of scarcely participatory processes, confined to the narrow scope of a Parliament dominated by the political and economic elites of the country in which the people could not participate effectively, and public opinion was kept at bay. That was in part the reason why the old constitutionalism did not care much about anything but to comply with the objectives determined by these same elites: to organize the power of the State in order to maintain the status quo, to provide mechanisms for the ordered 
succession in power of these elites, and at the most to display a few of the characteristic elements of a formal democratic system.

\section{The Formal Aspects of The New Latin American Constitutionalism}

Alongside with this similarity regarding the popular origin of this set of Constitutions, and adopting now a strictly formal point of view, at least four other common features deserve to be underlined:

- Their originality and potential for innovation.

- The unprecedented extension of their texts.

- The complexity of the institutional framework created.

- And their extreme rigidity.

The apparent originality of the constitutions that make "The New Latin American Constitutionalism" is inherent to their claim to serve as a vehicle to a profound political and social change in the direction of enhancing social integration, ensuring rights and freedoms, and deepening citizens' channels for political participation. Examples of this claim to originality start in two of these texts with the introduction of a change nothing less than in the name of the State itself, whereby the Republic of Venezuela became the "Bolivarian Republic of Venezuela" in 1999; and the Republic of Bolivia the "Plurinational State of Bolivia" in 2008. But, indeed, they fully affect the institutional design of these States with for example- the institutionalization of the referendum of recall in the case of Colombia, Venezuela and Bolivia; the creation of the Council of Citizen Participation and Social Control in Ecuador; the improvement in Venezuela of the traditional tripartite division of powers; or in the Bolivian case, the incorporation of the concept of "plurinationality" or the popular election of the members the higher courts of Justice of the State. Nevertheless, it will be the incorporation of a wide range of rights, many of them unheard of not only in their respective countries, but even in the most advanced Constitutional systems of the world, which has given these texts a genuinely revolutionary appearance -and an undisputable popular support (Noguera Fernández, 2011)

Another common, easily detectable, formal feature of these constitutions is its abnormal extension: in addition to other elements, such as the preamble, the transitional provisions, etc., the 1991 Colombian Constitution has 380 sections; the Ecuadorian of 1998, 284; the Venezuelan of 1999, 350; the Ecuadorian of 2008, 444 sections and finally the Bolivian Constitution of 2009, comprises 411 sections, many of which also happen to be long, detailed, and even casuistic texts, sometimes extending for one page or more. This 
clearly excessive regulatory zeal has been usually justified by three kinds of reasons: on the one hand by the desire of the constituent assembliesto carry out a sweeping, and immediate transformation of the State structure at all levels; on the other for the need -or at least the aspiration- to provide an answer to a myriad of real or perceived problems, and to satisfy the demands of many social actors taking part in extremely open and widely participatory constitution-making processes; and finally by the desire to guarantee the permanence of the agreements reached throughout these processes, preserving them as far as possible from the forgetfulness -or the betrayal-of future governments or parliamentary majorities to be conformed once the Constitution entered into force even if they may have a different set of priorities. All this with the logical consequence of severely limiting the powers and freedom of action of these future governments and parliaments-and even that of constitutional courts-, in their role of developers and interpreters of the constitutional text, which would forcefully be hampered by the extreme casuistry and precision of these texts.

The complexity of the institutional framework created by this set of constitutions has a lot to do with the three aims just mentioned, and has resulted in a series of institutional systems of mammoth dimensions, in which the three classic branches of government -legislative, executive and judiciary-have often been complemented by others, newly created, all of them complemented by a myriad of surveillance, advice and participation organs. The most revealing consequence of these complex institutional designs is undoubtedly the departure from the classical principle of unity and hierarchy of the law which derives from the recognition indigenous peoples' legal systems on an equal footing with the law deriving from the Constitution itself, which has had as a consequence a duplication of standards, procedures and institutions difficult to fit and even more difficult to implement (Giraudo, 2008).

As for the constitutional rigidity (Grisolía González, 2007), it has been argued that this does not seek the durability of the constitution in time, as much as making sure that changing it will run exclusively at the expense of a constituent assembly, and will not be carried out by means of a behind-the-doors agreement and a ratification vote at the legislature. This has resulted in the deprivation of ordinary institutions of the capacity to carry out constitutional reform themselves. A claim that will not escape by its mere utterance of the iron rule under which, when constitutions are too rigid, the change in the political situation or the transformation of the social circumstances under which they were conceived necessarily leads to their blatant violation, or to their forceful and illegal 
replacement. Both of them hypothesis far less desirable -despite what the advocates of this new constitutionalism, apparently unsure of their durability in time, may sustain- that their gradual transformation.

\section{The Proposals of The New Latin American Constitutionalism}

Of course, the claim that there is such a thing as a "New Latin American Constitutionalism" would become pointless if, beyond the geographical, temporal, and formal coincidences that we have underlined so far, there were not substantive similarities among the political projects proposed by the different constitutional texts which we are taking as a reference. But these similarities do exist, and at least some of them deserve some consideration (Pazmiño Freire, 2009).

1st. The replacement of the idea of representative democracy, so characteristic of the classic liberal tradition, by a system of participatory and pluralistic democracy, which not dismissing the well known and deeply rooted representative bodies-, complements them with mechanisms of direct democracy and citizens' control, developing a democratic paradigm much closer to Rousseau's ideal that to the more pragmatic and workable approach of Montesquieu (De Cabo, 2011). Thus, the New Latin American Constitutionalism has institutionalized a whole set of popular participation formulas, such as the popular legislative initiative (Hevia, 2010), the referendum (Soto Barrientos, 2013), recall procedures of elected officials (Welp \& Serdült, 2014), the programmatic vote, el cabildo abiertoor open local assemblies (Alvarado Beltrán, 2014), popular control bodies and electoral justice, and direct eligibility of the highest courts of justice, in addition to the aforementioned permanent activation of the regulatory capacity of the people as true holder of the constituent power. But it has also been concerned to encourage non-institutionalized forms of citizen participation in order to avoid the bureaucratization and state monopoly of political participation and to keep the so-called social or non-institutionalized guarantees of rights. As a consequence, New Latin American Constitutionalism is characterized by the juxtaposition of two complementary -though the sometimes confronted-areas for political participation: the institutionalized one, which contributes to democracy and state legitimacy, and the informal one, ensuring social supervision and control over state powers.

2 nd. The constitutionalization of international human rights instruments, and the proclamation of their supremacy over internal rules: in most of these constitutions human rights standards deriving from international instruments ratified by the States are directly incorporated into their constitutional order, with a higher rank to the rest of the system, 
including them in what the doctrine calls the "constitutional block." A trend that is perhaps not striking when view from Europe but that certainly is novel in the Latin American continent, where the idea of state sovereignty is still deeply rooted (Cordeiro Lopes, 2015).

3rd. The abandonment of federalism and autonomy in favor of a recentralization of the State. It is known that in Latin America, and largely as a result of US influence, federalism has a long tradition. However, this tradition has proved unable to provide any of the countries that have formally adopted federalism (Mexico, Argentina, Brazil and Venezuela) with a genuinely federal dynamic, and therefore has not managed to become an obstacle to the concentration of power in the hands of a centralist elites. Despite this disheartening precedent, in the last quarter century, and with the rise of neoliberalism, the federal idea took a new strength both in those Latin American countries that had already assumed it, as well as in others-the pressure for regionalization in Bolivia is probably the most paradigmatic case (Burbano de Lara, 2012)-that were still keeping radically centralist formulas despite the obvious diversity of their territories and their respective demands. This renewed demand for federalism -or, following the term coined by the Spanish Constitution of 1978, of "autonomy"- was focused not only on the transfer and joint management of the most important governmental powers, but especially on the direct management of natural resources located in the respective territories and the administration of their benefits, with the consequence of increasing regional inequalities wherever this trend was able to prosper, and the strengthening of alternative power centers. Probably for this reason the New Latin American Constitutionalism appears determined to put a limit to, or even reverse these processes, restructuring the system of division of powers from a centralist conception of planning and control of resources that, in theory, will facilitate the re-institutionalization of the State and ensure the satisfaction of the social demands of the population. At the same time, the above mentioned constitutions offered to replace territorial self-government with alternative kinds of self-government based on ethnic divisions(Cómez Isa \& Ardanaz Iriarte, 2011) which may be justifiable from other points of view, but that in no way met the demands of those who had advocated a horizontal division of powers.

4th. A new approach to constitutional justice, through the transformation of the traditional system of judicial review imported from the US into a hybrid system closer to the European model of constitutional control, though not lacking in substantial and significant peculiarities. Although the creation of constitutional courts or separated constitutional sections in the supreme courts was not an innovation of the New Latin American Constitutionalism -the former existed since 1984 in Guatemala, 1993 in Peru and 
1994 in Bolivia, and the second had been created in 1983 in El Salvador, en 1989 in Costa Rica and in 1992 in Paraguay- the truth is that the idea of concentrated control of constitutionality got a warm reception in the series of constitutions we are analyzing, which however did not imply the complete abandonment of the system of judicial review of constitutionality. Thus, the Latin American model of constitutional control has ended up being a unique mixture where on the one hand there are constitutional courts in charge of keeping the integrity and supremacy of the Constitution, while the ordinary courts retain the power to refuse the application of the laws and unconstitutional regulations in specific cases, in addition to the function of hearing appeals for protection of basic rights (Storini \& Escudero Soliz, 2011).

5th. The marginalization of parliament as a representative body and of political parties as tools for political participation. To begin with, it should be recalled that the aforementioned assumption by the new Latin American constitutional orders of the normative character of all the constitutional provisions and the central role assumed by the dogmatic part of the constitution, has led to the direct applicability -that is: without the necessary intermediation of the legislature- of most constitutional regulations, including many recognizing economic, social and cultural rights. On the other hand, the argument that it was necessary to carry out the people's demands as quickly as possible, also served as an alibi by the various presidents of the region to demand from parliaments special powers on their behalf, or to marginalize them in the decision-making process by issuing executive decrees in lieu of acts of Parliament. Both trends have led to a tacit, global devaluation of the law and therefore of the legislatures, on behalf of constituent power and the set of organs to whom it entrusts the protection of its legacy; and more often of the chief executive. Legislatures have undergone a serious discredit process, too, in favor of institutions of control of the hierarchy of norms such as courts, which in turn has required the introduction of mechanisms for popular election and recall of their leaders. The main protagonists of their action - political parties- have been equally discredited as the sole channels for political participation, recruitment and representation, in favor of informal formulas for participation of citizens in the definition of the political course of the country.

$6^{\text {th }}$. A new structure for the separation of powers. Not satisfied with that, some of these constitutions have gone even further, attempting to overcome the paradigmatic juxtaposing of the three traditional branches of power-legislative, executive and judicial-by introducing a whole set of new instances such as the "electoral power" mentioned in the 1991 Constitution of Colombia, or the "moral power" established by the Venezuelan 1998 
Constitution (Criado de Diego, 2011). The former appeared as a consequence of the hyperconstitutionalization of electoral rules, consisting in the inclusion within text of the Constitution of electoral norms that were not just a matter of principle, but strictly procedural, hence assuming that channeling the people's will through the vote was a matter unsuitable to be regulated by any of the state powers that sustain their legitimation on this will, but only by one of independent nature, exercised directly by the citizens themselves, and indisputably committed to constitutional values. As for the power known as "citizen" or "moral power", this happens to incarnate a new governmental role, unprecedented in European constitutionalism, intended to institutionalize the participation of organized citizens in monitoring and controlling the ordinary operation of state institutions. This function is designed as a manifestation of the right and the duty, belonging to every citizen in the context of a participatory democracy, to be informed, participate, decide and evaluate the management of public issues of all kinds. As a consequence, a whole new network of specialized agencies became established, such as the Comptroller General of the State, ombudsmen, or supervisory instances based on institutionalized citizen involvement, such as the Council of Citizen Participation and Social Control (Palacios Romero, 2011).

$7^{\text {th }}$.The recognition of the multiethnic and multicultural character of Latin American nations, with the consequent creation of legal mechanisms aimed at preserving and enhancing the cultural, social and political peculiarities of indigenous peoples of America. Brazil (1988), Colombia (1991), Paraguay (1992), Peru (1993), Mexico (1994), Ecuador (1996 and 1999) and Venezuela (1999) have incorporated into their constitutions entire chapters that regulate new forms of articulation of the institutional relationship between the state and indigenous peoples, as well as the explicit recognition of constitutional rights not only forindividuals but, more importantly, for indigenous peoples as such, now considered as collective subjects of rights. Bolivia (2009) has gone even further by incorporating the traditional values of their indigenous peoples to the country's own cast of constitutional values, providing legal validity to indigenous law, and even changing its official name in order to echo this plurality: it is so that Article 8 of the Constitution of the "Plurinational State of Bolivia" stated that it "assumes and promotes as ethical and moral principles of the plural society: ama qhilla, ama Ilulla,amasuwa (do not be lazy, do not be a liar do not be a thief), sumaqamaña (live well), Nandereko (live in harmony), TekoKavi (have a good life), ivimaraei (land without evil) and qhapajĩan (live a noble life)" (Obets, 2009).

Two aspects of this issue deserve to be highlighted. First, the extent to which most of these constitutions have reflected collective rights aimed at protecting the ethnic and 
cultural integrity of these peoples (Martí Puig, 2007). Rights which typically include (1) the right to an identity; (2) the right to a territory; (3) the right to self-development; (4) the right to autonomy and, finally, (5) the right to participate, whose most important manifestation is reflected in the legal obligation to consult, or follow the binding opinion, of indigenous authorities regarding any public or private initiative likely to affect directly or indirectly to a particular community.

The second is the impact this has had on the system of sources of law. The well established principles of unity, cohesion and hierarchy of the legal systems inspired by the kelsenian principles has been replaced by a fragmented system, integrated by no less than three different normative orders: (1) The general state legislation, applied equally to all citizens of the country, including those belonging to indigenous peoples; (2) The special indigenous legislation, developed as a measure of affirmative action, and composed of international conventions and treaties, and constitutional, statutory and regulatory provisions that establish a special set of rights and guarantees for the benefit of indigenous peoples; and (3) the traditional legal systems of these communities who are recognized by the Constitution, and are applicable to indigenous territories, integrated by the rules, institutions, customs, procedures and methods of social control and regulation distilled by the cultural traditions of each of indigenous community, which naturally have particular conceptions of law, justice, authority, power and political representation (Cabedo Mallol, 2012). This does not occur, strictly speaking, through the validation of decisions adopted by the institutions of a given indigenous community and their inclusion within the State legal order after determining its precise position within this system, but as a consequence of the juxtaposition of different equal, independent regulatory orders, complementary among each other and in a position of horizontal collaboration. What, in short, amounts to the disappearance of the state monopoly of the sources of the law, so capital in the legal tradition of Western constitutionalism.

8th. The strengthening of state intervention in all spheres of social life, and especially in the field of economy. On the basis of a thorough constitutional regulation of their future economic model and financial system, all countries embracing the New Latin American Constitutionalism have ended up increasing exponentially the interventionist role of the state in the economy (Maestro Buelga, 2011), underlining the importance of state planning and control over the market, ruling that key economic sectors should be exclusively, or mainly, run by the state, and subsequently adopting measures for the expropriation of strategic companies, the creation of State-owned companies, the 
introduction of price controls, currency exchange limits, control on banks, etc. Anyway, this growing state intervention has not been limited to the economic sphere, but has affected many other areas as press and television, having as a consequence numerous clashes with independent media, and even the closing of several of them. Far from being the result of specific political decisions, most of these have enjoyed a clear constitutional support, of which a good example are the constant references to the state's role in guaranteeing the social control over the extraction and commercialization of natural resources in -or more frequently, under- Bolivian soil contained in the 2009 text, or the references of the Ecuadorian constitution to the role of the state in "seeking plurality and diversity in the communication process" and making sure that information received by citizens is "true" (Sánchez \& Resina de la Fuente, 2014).

\section{Conclusions}

Making a fair assessment of the New Latin American Constitutionalism is still a risky task today. It is so, first, because most of the constitutions that we have decided to frame under this category have not even gotten to celebrate its first decade of life, which confronts us with periods too short to allow sufficiently substantiated value judgments. And it is so, in second place, because the most significant among these -the 1999 Venezuelan, the 2008 Ecuadorian and the 2009 Bolivian Constitutions- have not yet passed the key test of being applied by political forces of opposite sign to those that promoted them, since the Presidents under whose leadership those processes took place -Morales in Bolivia, Correa in Ecuador, and President Maduro, successor of the deceased Chavez in Venezuelacontinue in power in their respective countries. So, any assessment of their performance is bound to be conducted under the risk of being mistaken in identifying the causes of their failure - or of their success - by confusing the consequences of the way in which the constitutional framework was designed, fromthose resulting from the specific policies implemented by the governments in power at a given moment.

However, from the analysis of the specific wording of the clauses contained in these constitutions it is still possible to advance at least several conclusions, in principle detached from their adequate or inadequate practical application by the existing governments.

First: the excessive thoroughness of their articles, together with the remarkable rigidity of their texts, is bound to distort in a potentially problematic manner the always complex relationship between the constituent power and constituted powers, in favor of the former, and against the latter. The prevailing idea in liberal constitutionalism has always 
been that constitutions should limit themselves to the recollection of the basic political principles that were to sustain the political system, and to outline its institutional design, leaving the formulation of specific policies to governments to come, emerging from periodical elections. But the regulatory zeal of these constitutions, however, is called to render the agendas of future governments meaningless, and to make political alternation a defining character of democratic systems - more difficult than ever, which implies a destabilizing potential that in times to come will certainly become manifest.

Second: if one of the defining elements of the New Latin American Constitutionalism is the extent to which it's economic and social rights are regulated, this also appears to be one of its most vulnerable aspects. Unlike what happens with individual and political rights, the effective implementation of social and economic rights requires large budgetary allocations, which in turn depend on the state of government finances, and this on the global economic environment. And in countries still developing, such as Bolivia and Ecuador, or mired in a serious recession as it is the case with Venezuela, sustaining these promises may prove impossible, which would generate not only a glaring breach of the Constitution but, most likely, a significant disaffection on the side of the citizenry. This also represents a not inconsiderable problem.

Third: as argued above, the analyzed constitutional texts contain in all cases formulas aimed at giving coverage to a growing state interventionism in economic and social life. These are clauses which, applied with moderation, could contribute to mitigate the traditional social inequalities of Latin American countries; but if applied radically, they could lead to a reduction of political freedoms and the establishment of a command economy, as has as happened in Venezuela, embarked for years now in the construction of a regime openly described as "socialist". And if the former might be defensible, the latter is entirely objectionable.

And fourth: if the economic development, the social integration, and the political empowerment of indigenous communities is an unavoidable target in any regime that wants to be truly democratic, the way in which the New Latin American Constitutionalism has carried this out is somewhat less defensible. The elevation of these communities to the status of most genuine incarnation of the nation, to the detriment of those ample social sectors defined as mestizos, has replaced the old negative discrimination by another of opposite sign, but equally discriminatory. And above all, it has introduced the principle of ethnification of political life, under which individuals first have to become members of a 
community, and only then they can interact as citizens of the Republic. Something that, under the light of the most profound democratic paradigms, is also objectionable.

\section{Bibliography}

1. Alvarado Beltrán, A. M. (2014), "El Cabildo abierto en Colombia", Revista de Derecho UNED 14: 79-100.

2. Ávila Santamaría, R., Grijalva Jiménez, A. \& Martínez Dalmau, R., eds. (2008), Desafios constitucionales: la Constitución ecuatoriana del 2008 en perspectiva, Quito: Ministerio de Justicia y Derechos Humanos.

3. Bravo Lira, B. (1989), "La Constitución de 1988 en Brasil: Trasfondo histórico e institucional", Anuario Mexicano de Historia del Derecho, 1: 47-75.

4. Burbano de Lara, F. (2012), Movimientos regionales y autonomías politicas en Bolivia y Ecuador, PhD Thesis, Salamanca: Universidad deSalamanca.

5. CabedoMallol, V. (2012) Pluralismo Jurídico y Pueblos Indigenas, Madrid: Icaria.

6. Chivi Vargas, I. M., ed. (2010), Nueva Constitución Politica del Estado. Conceptos elementales para su desarrollo normativo, La Paz: Vicepresidencia del Estado Plurinacional de Bolivia.

7. CordeiroLopes, A. H. (2015), La integración de los derechos humanos en América Latina, PhD Thesis, Sevilla: Universidad de Sevilla.

8. Criado de Diego, M. (2011), "El sistema de gobierno en las nuevas constituciones andinas: distribución horizontal del poder en el régimen constitucional de Venezuela y Ecuador", Revista General de Derecho Público Comparado, 9: 1-44.

9. De Cabo, C. (2011), "Los mecanismos de democracia participativa en el nuevo constitucionalismo latinoamericano", Revista General de Derecho Público Comparado, 9: 1-40.

10. Fernández Segado, F. (1994), “El nuevo ordenamiento constitucional del Perú: aproximación a la Constitución de 1993", Revista de Estudios Políticos, 84: 27-68.

11. Camboa, F. (2011), Dilemas y Conflictos Sobre la Constitución en Bolivia: ¿Por qué y Cómo Fracasa una Asamblea Constituyente.Editorial Académica Española.

12. Giraudo, L., coord., (2008), Derechos, costumbres y jurisdicciones indigenas en América Latina contemporánea, Madrid: CEPC. 
13. Gómez Isa, F. \& Ardanaz Iriarte, S. eds., (2011), La plasmación politica de la diversidad: autonomía y participación politica indígena en América Latina, Bilbao: Universidad de Deusto.

14. Grisolía González 0. (2007), La revisión constitucional en Venezuela, PhD Thesis, Madrid: UNED.

15. Hevia, F. J. (2010), "La iniciativa legislativa popular en América Latina", Convergencia: Revista de ciencias sociales, 52: 155-186

16. Jiménez, E. P. (2004), "La reforma constitucional argentina de 1994: una evaluación de contenidos, diez años después", Cuadernos Constitucionales,47: 5-12.

17. Maestro Buelga, G. (2011), "Estado y mercado en el nuevo constitucionalismo latinoamericano", Revista General de Derecho Público Comparado, 9: 1-30.

18. Martí Puig, S., ed. (2007), Pueblos indigenas y politica en América Latina: el reconocimiento de sus derechos y el impacto de sus demandas a inicios del siglo XXI, Barcelona: Fundación CIDOB.

19. Martínez Dalmau, R. (2006), "El proceso constituyente venezolano de 1999: un ejemplo de activación democrática del poder constituyente", in Roberto Viciano Pastor, R. \& Salamanca, L., eds. (2006), cit. infra: 27-46.

20. Martínez Sospedra, M. (1995), "La Constitución militante. El concepto de constitución en la jurisprudencia de la Corte de Constitucionalidad de Guatemala", Cuadernos Constitucionales,14/15: 95-140.

21. Noguera Fernández, A. (2011), "Derechos económicos, sociales y culturales en el nuevo constitucionalismo latinoamericano", Revista General de Derecho Público Comparado, 9: 1-33.

22. Noguera Fernández, A. \& Criado de Diego, M. (2011), "La constitución colombiana de 1991 como punto de inicio del nuevo constitucionalismo en América Latina", Revista Estudios Socio-Jurídicos,13/1: 15-49.

23. Obets. Revista de Ciencias Sociales (2009), "Buen vivir, desarrollo y maldesarrollo", Obets. Revista de Ciencias Sociales, 4 [monographicissue]: 11-83.

24. Palacios Romero, F. J. (2011), "El mito de la separación del poder judicial en el constitucionalismo clásico y la nueva configuración participativa en Latinoamérica: (En torno a una aporía del constitucionalismo clásico: Quiscustodietipsoscustodes?)", Revista General de Derecho Público Comparado, 9: 1-49. 


\section{Securiaty}

25. Pazmiño Freire, P. (2009), "Algunos elementos articuladores del nuevo constitucionalismo latinoamericano", Cuadernos constitucionales, 67/68: 27-54

26. Sánchez, F. \& Resina de la Fuente, J.(2014), "Los que "no se representan ni a ellos mismos": medios de comunicación y oposición partidista en el Ecuador", Cuadernos constitucionales, 77/78: 203-219

27. Soto Barrientos, F. (2013), El referéndum en Latinoamérica: un análisis desde el Derecho comparado", Boletín Mexicano de Derecho Comparado, 136: 317-346.

28. Storini, C. \& Escudero Soliz, J. (2011), "El control de constitucionalidad en el nuevo constitucionalismo latinoamericano", Revista General de Derecho Público Comparado, 9: 1-33.

29. Trujillo Vásquez, J. C., Viciano Pastor, R. \& Andrade Ubidia, S., eds. (2005), Estudios sobre la Constitución ecuatoriana de 1998, Valencia: Tirant lo Blanch.

30. Viciano Pastor, R. \& Martínez Dalmau, R. (2010), "Los procesos constituyentes latinoamericanos y el nuevo paradigma constitucional", Revista lus, 25: 10-16.

31. Viciano Pastor, R. \& Martínez Dalmau, R. (2011), "El nuevo constitucionalismo latinoamericano: fundamentos para una construcción doctrinal", Revista General de Derecho Público Comparado, 9: 1-24.

32. Viciano Pastor, R. \& Salamanca, L., eds. (2006), El sistema politico en la Constitución Bolivariana de Venezuela, Valencia: Tirant lo Blanch.

33. Welp, Y. \&Serdült, U., eds., (2014), La dosis hace el veneno: análisis de la revocatoria del mandato en América Latina, Estados Unidos y Suiza, Quito: Consejo Nacional Electoral / Instituto de la Democracia. 